\author{
PRIMARY: JURNAL PENDIDIKAN GURU SEKOLAH DASAR \\ VOLUME 9 NOMOR 3 JUNI 2020 \\ ISSN: 2303-1514 | E-ISSN: 2598-5949 \\ DOI : http://dx.doi.org/10.33578/jpfkip.v9i1.7905 \\ https://primary.ejournal.unri.ac.id/index.php/JPFKIP
}

\title{
THE STUDY OF EDUCATION QUALITY ASSURANCE SYSTEM TO IMPROVE THE QUALITY OF PRIMARY SCHOOLS AT SD N 2 BENDOSARI BOYOLALI
}

\author{
Santri Prabowo Utomo ${ }^{1}$, Sri Marmoah ${ }^{2}$, Roemintoyo $^{3}$ \\ 1,2,3 Universitas Sebelas Maret, Surakarta, Indonesia \\ ${ }^{1}$ santriprabowoutomo@gmail.com, ${ }^{2}$ marfuah_pt@yahoo.co.id, ${ }^{3}$ roemintoyo@yahoo.co.id
}

\section{KAJIAN SISTEM PENJAMINAN MUTU PENDIDIKAN UNTUK MENINGKATKAN KUALITAS SEKOLAH DASAR PADA SD N 2 BENDOSARI BOYOLALI}

\begin{abstract}
ARTICLE INFO
ABSTRACT

Submitted:

05 Mei 2020

$05^{\text {th }}$ May 2020

Abstract: If a system is arranged and implemented clearly, correctly, systematically, and reported responsibly, it will simplify the users' task. Therefore, the quality assurance system of education in primary schools is very important in accordance with existing procedures to maintain and advance the quality of education of a school. There needs to be an efficient, effective, and appropriate way to assure the quality of education in a school, namely primary schools. This study aims to describe the results of the analysis of the education quality assurance system at Bendosari SD N 2 (State Primary School 2), Sawit, Boyolali. The approach used in this research was a descriptive qualitative approach with case study design. This data collection technique was in the form of the results of observation activities, interview activities, questionnaire filling activities, and documentation activities. Sources of data in this study came from school residents such as: school committees, principals, teachers, students, parents of students, communities, and researchers. Data validity techniques to find the validity and validity of the data used data triangulation. Data analysis techniques used in this study were interactive qualitative data analysis by Miles and Huberman (2014) consisting of data reduction (summarizing data), data presentation (displaying data), and drawing conclusions from research. The results obtained in this study were to describe and explain that the quality assurance of education conducted by $S D N 2$ Bendosari, Sawit, Boyolali can be maintained properly and to improve the education quality assurance system in order to achieve a goal.
\end{abstract}

Accepted:

22 Juni 2020

$22^{\text {th }}$ June 2020

Published:

28 Juni 2020

$28^{\text {th }}$ June 2020

Keywords: school quality, education quality assurance, primary school

Abstrak: Sebuah sistem apabila disusun dan dilaksanakan secara jelas, benar, sistematis, dan dilaporkan dengan bertanggungjawab akan memudahkan bagi penggunanya. Maka dari itu sistem penjaminan mutu pendidikan di sekolah dasar sangat penting dan haus sesuai dengan prosedur yang ada untuk menjaga dan memajukan mutu pendidikan sebuah sekolah. Perlu adanya cara yang efisien. efektif, dan tepat untuk menjamin mutu pendidikan di sebuah lembaga sekolah yaitu sekolah dasar. Penelitian ini bertujuan untuk mendeskripsikan hasil analisis sistem penjaminan mutu pendidikan yang bertempat di Sekolah Dasar Negeri 2 Bendosari, Sawit, Boyolali. Pendekatan yang digunakan pada penelitian ini yaitu pendekatan kualitatif deskriptif dengan desain studi kasus (Case Study). Teknik pengumpulan data ini berupa hasil dari kegiatan observasi, kegiatan wawancara, kegiatan pengisian angket, dan kegiatan dokumentasi. Sumber data pada penelitian ini berasal dari warga sekolah seperti: komite sekolah, kepala sekolah, guru, siswa, orang tua siswa, masyarakat, dan peneliti. Teknik validitas data untuk mencari keabsahan dan kevalidan data menggunakan triangulasi data. Teknik analisis data yang digunakan dalam penelitian ini yaitu analisis data kualitatif interaktif oleh Miles and Huberman (2014) yang terdiri dari reduksi data (meringkas data), penyajian data (menampilkan data), dan penarikan kesimpulan penelitian. Hasil yang diperoleh pada penelitian ini untuk mendiskripsikan dan menjelaskan bahwa penjaminan mutu pendidikan yang dilakukan SD N 2 Bendosari, Sawit, Boyolali dapat terjaga dengan baik serta meningkatan sistem penjaminan mutu pendidikannya guna mencapai sebuah tujuan.

Kata kunci: kualitas sekolah, penjaminan mutu pendidikan, sekolah dasar

CITATION

Utomo, S.P., Marmoah, S., \& Roemintoyo. (2020). The Study Of Education Quality Assurance System To Improve The Quality Of Primary Schools At Sd N 2 Bendosari Boyolali. Primary: Jurnal Pendidikan Guru Sekolah Dasar, 9(3), 397-408. DOI: http://dx.doi.org/10.33578/jpfkip.v9i1.7905. 


\section{PRIMARY: JURNAL PENDIDIKAN GURU SEKOLAH DASAR VOLUME 9 NOMOR 3 JUNI 2020 \\ ISSN: 2303-1514 | E-ISSN: 2598-5949 \\ DOI : http://dx.doi.org/10.33578/jpfkip.v9i1.7905 \\ https://primary.ejournal.unri.ac.id/index.php/JPFKIP}

\section{PENDAHULUAN}

Pendidikan adalah sebuah upaya sadar yang dilakukan oleh seseorang dan digunakan untuk membentuk kualitas diri dengan cara menggali potensi diri pada manusia. Bukan merupakan hal umum lagi, pendidikan yang berkualitas dapat memanfaatkan perkembangan ilmu pengetahuan dan teknologi secara tepat dan optimal. Perlu adanya penggunaan ilmu pengetahuan dan teknologi yang tepat diiringi dengan sumber daya manusianya sebagai pengguna yang mempunyai kompetensi, agar diperoleh pendidikan yang berkualitas bagi masyarakat Indonesia. Upaya-upaya dalam mengatasi permasalahan dan memperbaiki kualitas pendidikan di Indonesia, terus digalakkan dan selalui diupaya oleh pemerintah. Bukti bahwa pemerintah terus melakukan upaya-upaya perbaikan kualitas pendidikan di Indonesia dengan serius yaitu berupa perubahan-perubahan pada otonomi daerahnya dalam mengatur pendidikan dan secara khusus pada kurikulumnya dalam rangka penjaminan mutu pendidikan suatu sekolah sesuai dengan tujuan pendidikan nasional Indonesia.

Tujuan dari perbaikan dan pemenuhan mutu pendidikan di sekolah tercantum pada UU RI Nomor 20 Tahun 2003 mengenai sistem pendidikan nasional Indonesia yaitu pada poin dasar, fungsi, dan tujuan pendidikan adalah "Pendidikan nasional berfungsi mengembangkan kemampuan dan membentuk watak serta peradaban bangsa yang bermartabat dalam rangka mencerdaskan kehidupan bangsa, bertujuan untuk berkembangnya potensi peserta didik agar menjadi manusia yang beriman dan bertakwa kepada Tuhan Yang Maha Esa, berakhlak mulia, sehat, berilmu, cakap, kreatif, mandiri, dan menjadi warga Negara yang demokratis serta bertanggung jawab". Proses dalam pemenuhan dan penetapan standar manajemen penjaminan mutu pendidikan dilaksanakan secara terus menerus dan konsisten sehingga pihak-pihak yang berkepentingan mendapatkan hasil kepuasan disebut penjaminan mutu pendidikan sekolah. Penjaminan mutu pendidikan ini, harus dilakukan oleh masingmasing lembaga di satuan pendidikan baik pada jalur formal maupun non formal.

Sebuah lembaga pendidikan yang menyatakan standar mutu seharusnya tidak hanya mempunyai ketentuan pengakuan akreditasi lembaga tersebut tetapi tentu harus dilengkapi dengan prosedur-prosedur mekanisme yang sistematis, rinci, dan jelas mengenai bagaimana penjaminan mutu lembaga pendidikan tersebut dijalankan. Meirawan (2010: 126) berpendapat dalam upaya menjaga mutu tersebut erat sekali kaitannya dengan pengelolaan mutu yang baik dalam mengahsilkan penjaminan mutu pendidikan yang terjaga dan berkualitas. Sebagai pengguna jasa pendidikan, masyarakat sangat memperhatikan kualitas mutu lembaga pendidikan tersebut, khususnya ditingkat sekolah dasar (SD) dan menjadi tolak ukur untuk mampu melanjutkan pada jenjang pendidika sekolah menengah pertama (SMP) yang berkualitas. Masyarakat berharap nantinya lulusan sekolah ini dapat bersaing pada era globalisasi. Maka dari itu, sebuah lembaga pendidikan harus mempunyai sistem penjaminan mutu pendidikan yang dikelola secara benar, jelas, rinci, dan dapat dipertanggung jawabkan.

Namun pada kenyataanya di lapangan ditemukan masih terdapat mutu pendidikan yang masih rendah, hal ini dikutp oleh Radar Kaltara yang ditulis oleh Pijai Pasarija, bahwa 8 pemenuhan standar penjaminan mutu masih berada dikatergori rendah. Pemenuhan mutu pendidikan ini harus didukung penuh dengan data jumlah sekolah yang berada di suatu wilayah. LPMP Kaltara (Kalimantan Utara) mengungkapkan bahwa dari jumlah sekolah 722 yang belum mengirimkan data EDS terdapat sekitar 179 sekolah. Mereka mengungkapkan hal itu dikarenakan tidak seluruh sekolah memiliki jaringan internet untuk mendukung pengiriman, masih terdapat sekolah yang masih belum memahami mengenai bagaimana penggunaan sistem penjaminan mutu pendidikan ini, dan masih banyak lagi sekolah yang belum terdata sehingga 
terlambat bahkan tidak bisa mengirimkan data. Jadi pencapaian dalam tujuan pendidikan nasional masih jauh dari harapan, berbagai upaya peningkatan, dan upaya perbaikan juga telah dilakukan pemerintah, seharusnya hal ini dapat berdampak pada meningkatnya mutu pendidikan yang berkualitas dan dapat bersaing (Alawiyah, 2012: 64).

Berdasarkan kajian tersebut, ditemukan hasil data empiris berupa observasi dan wawancara yang kemudian peneliti analisis, bahwa pelaksanaan penjaminan mutu pendidikan di SD N 2 Bendosari, Sawit, Boyolali menunjukkan bahwa kinerja berbagai pihak belum maksimal dilakukan, hal ini terlihat dari hasil wawancara guru dan kepala sekolah yang berpendapat bahwa mereka belum sepenuhnya memahami sistem pemenuhan penjaminan mutu pendidikan dalam hal apa yang harus dilaksanakan, apa yang harus dipenuhi, dan apa yang harus dilaporkan. Persoalan mengenai keterpurukan mutu pendidikan tersebut menjadi suatu kajian penting yang perlu dibahas untuk perbaikan kualitas pendidikan dalam mencapai tujuan pendidikan Nasional. Hal ini karena pendidikan merupakan pondasi fundamental pembangun di berbagai bidang, semakin berkualitas pendidikan maka semakin berkulitas pula sumber daya manusianya. Perlu dilakukan usaha-usaha yang berupa sebuah sistem prosedur bagaimana dalam memenuhi penjaminan mutu pendidikan dalam suatu lembaga pendidikan sekolah.

Batasan dalam penelitian ini yaitu implementasi penjaminan mutu pendidikan pada sekolah dasar, yang merupakan tingkat awal dalam perjalanan pendidikannya yakni dalam melakukan proses pembelajaran di sekolah ini ditekankan pada pengembangan dan inovasi pembelajaran dalam menggunakan ide-ide baru pada delapan standar nasional melalui studi lapangan untuk menghasilkan suatu informasi realita pelaksanaan penjaminan mutu dilengkapi dengan data dan dokumen yang ada. Hal ini didukung dengan penelitian relevan yang dilakukan oleh Kusnandi (2017: 107-108) mengungkapkan bahwa pentingnya sistem penjaminan mutu pendidikan dilakukan untuk mencapai peningkatan melalui suatu sistem standarisasi dan kemampuan yang menuntut berbagai pihak untuk berkerjasama dan bersinergi dalam pelaksanaannya yaitu sebuah sistem EDS (Evaluasi Diri Sekolah). Senada dengan penelitian yang dilakukan Haryono (2019: 21) berpendapat bahwa semua komponen sekolah harus membangun budaya perbaikan mutu berkelanjutan di sekolah yang nantinya akan menjadi fokus dari upaya penjaminan mutu dan perbaikan mutu pendidikan di sekolah.

Suatu kebijakan pendidikan dalam menjamin dan melaksanakan pemenuhan penjaminan mutu pendidikan memiliki sebuah standar dalam pelaksanaannya dan memerlukan sumber daya manusia sebagai pendidik dan tenaga kependidikan dalam menjamin mutu pendidikan yang dilaksanakan oleh suatu lembaga pendidikan tersebut. Masing-masing standar penjaminan mutu pendidikan inimemiliki peran yang dilakukan secara terpadu dan terintegrasi berupa sistem tersendiri. Sistem pemenuhan untuk penjaminan mutu pendidikan ini didasarkan pada kebijakan yang dirumuskan BSNP (Badan Standar Nasional Pendidikan) yang harus dilaksanakan melalui sebuah sistem Standar Operasional Prosedur (SOP), yaitu 1) sistem pemenuhan standar isi; 2) sistem pemenuhan standar proses; 3) sistem pemenuhan standar kompetensi lulusan; 4) sistem pemenuhan standar pendidik dan tenaga kependidikan, 5) sistem pemenuhan standar sarana dan prasarana; 6) sistem pemenuhan standar pengelolaan; 7) sistem pemenuhan standar pembiayaan; dan 8) sistem pemenuhan standar penilaian pendidikan..

Penjaminan mutu pendidikan ini akan berguna jika standar operasional prosedurnya dikelola dengan baik, dianalisis secara teliti, dan mudah dipahami oleh pemangku kepetingan terkait. Ada dua prinsip yang mendorong perlunya untuk menjamin mutu pendidikan menurut pendapat Satori (2010: 15) yaitu: 1) meningkatkan strategi pengumpulan data sehingga data yang terkumpulkan menjadi relevan, valid, dan andal; 2) menjamin bahwa data dipergunakan secara efektif untuk tujuan perencanaan, pengambilan keputusan dalam perencanaan dan alokasi sumber daya guna peningkatan mutu pendidikan. Berdasarkan uraian- 


\section{PRIMARY: JURNAL PENDIDIKAN GURU SEKOLAH DASAR VOLUME 9 NOMOR 3 JUNI 2020 \\ ISSN: 2303-1514 | E-ISSN: 2598-5949 \\ DOI : http://dx.doi.org/10.33578/jpfkip.v9i1.7905 \\ https://primary.ejournal.unri.ac.id/index.php/JPFKIP}

uraian di atas, penelitian ini penting untuk dilakukan dan bermanfaat secara umum guna memberikan pemahaman mengenai program sistem program penjaminan mutu pendidikan sekolah, dan Evaluasi Diri Sekolah (EDS) dalam pemenuhan 8 standar komponen pendidikan dalam implementasi penjaminan mutu pendidikan sebagai upaya meningkatkan mutu pendidikan, maka dari itu peneliti tertarik untuk mengangkat judul penelitian yaitu "Kajian Sistem Penjaminan Mutu Pendidikan pada Sekolah Dasar Untuk Meningkatkan Kualitas Sekolah Dasar Pada SD N 2 Bendosari Boyolali”.

\section{METODE PENELITIAN}

Penelitian yang dilaksana ini menggunakan pendekatan penelitian kualitatif dengan metode studi kasus (Case Study). Menurut Sugiyono (2013: 15) metode penelitian kualitatif studi kasus adalah metode penelitian di mana fokus pada penelitian yang diteliti terletak pada fenomena peristiwa yang terjadi secara alami pada masa kini yang secara fakta dan sesuai dengan realita kehidupan dunia nyata bukan dibuat-buat karena peneliti bukan orang yang mempengaruhi peristiwa tersebut, hanya sebagai pengamat/observer yang memiliki sedikit peluang untuk mengontrol peristiwa yang diselidiki di mana biasanya pokok pertanyaan rumusan masalahnya adalah how (bagaimana) atau why (mengapa). Pada penelitian ini, difokuskan mengenai fenomena yang sedang terjadi yaitu mengenai bagaimana prosedur keberhasilan Implementasi Penjaminan Mutu Pendidikan (PMP) Sebagai Upaya Meningkatkan Mutu Pendidikan di SD Negeri 02 Bendosari. Penelitian ini dilakukan pada sebuah lembaga pendidikan yaitu di SD Negeri 2 Bendosari, Sawit, Boyolali.

Adapun pelaksanaan penelitian mulai bulan Januari 2020 sampai April 2020. Data yang dikumpulkan pada penelitian ini berasal dari data kualitatif yang merupakan hasil pengumpulan data menggunakan teknik mengumpulkan data yang sudah disiapkan. Teknik pengumpulan data yang digunakan berupa observasi, wawancara secara mendalam, pengisian angket dan dokumentasi foto dan video. Insrumen pengumpulan data pada penelitian kualitatif ini adalah peneliti sendiri. Peneliti sebagai instrumen kunci penelitian yang dilengkapi dengan panduan observasi, pedoman wawancara, angket dan dokumentasi. Peneliti melakukan observasi langsung terhadap berbagai program kegiatan yang berlangsung di SD N 2 Bendosari. Peneliti juga melakukan wawancara dengan warga sekolah mulai dari Komite sekolah, Kepala Sekolah, Guru, Karyawan, Orang tua siswa, Siswa, dan Masyarakat. Dokumentasi berupa foto-foto dan video pendukung guna memperkuat bukti penelitian di sekolah yang menunjukkan delapan standar terpenuhi demi mencapai penjaminan mutu pendidikan sekolah tersebut.

Subjek penelitian adalah 3 komite sekolah, 1 kepala sekolah, 6 orang guru kelas, 1 orang guru mapel PJOK, 1 orang guru mapel PAI, 1 orang penjaga sekolah 9 siswa ( 3 kelas IV, 3 kelas V, dan 3 kelas IV), 3 orang tua siswa yang termasuk masyarakat sekitar. Pemilihan subjek pada siswa, dan orang tua siswa ini menggunakan teknik purposive sampling, yaitu agar dalam penentuan sampel ini berdasarkan pada kriteria yang telah ditentukan peneliti. Penelitian ini difokuskan pada pemahaman mengenai sistem pemenuhan penjaminan mutu pendidikan melalui wawancara, observasi, dokumentasi, dan pengisian sebuah angket. Hal ini akan memperoleh data-data yang selanjutnya perlu untuk dianalisis secara mendalam. Kriteria yang digunakan, agar sebuah data dapat dikatakan valid dan sah yaitu kepastian (confirmability), keteralihan (transferability), ketergantungan (dependability), dan kepercayaan (crediability).

Penelitian ini menggunakan derajat kepercayaan triangulasi data, pengumpulan data hasil observasi berupa catatan di lapangan, data hasil dokumentasi berupa surat-surat penting dan dokumen tertulis sekolah penting lainnya, serta 


\section{PRIMARY: JURNAL PENDIDIKAN GURU SEKOLAH DASAR VOLUME 9 NOMOR 3 JUNI 2020 \\ ISSN: 2303-1514 | E-ISSN: 2598-5949 \\ DOI : http://dx.doi.org/10.33578/jpfkip.v9i1.7905 \\ https://primary.ejournal.unri.ac.id/index.php/JPFKIP}

data hasil wawancara yang berupa transkip wawancara kepala sekolah, guru, karyawan sekolah dan siswa. Triangulasi data juga dilakukan melalui pengecekan data kepada narasumber dengan cara dibandingkan hasil transkip satu sama lain dan dibuat sebuah kesimpulan akhir. Hasil transkip wawancara tersebut agar dijamin keabsahan datanya peneliti meminta informan untuk memberikan catatan, tambahan informasi, dan diberikan pengesahan paraf bahwa benarbenar telah diwawancarai. Pemilihan analisis data ini bertujuan agar data yang diperoleh lebih bermakna digunakan untuk memperoleh suatu hasil kesimpulan terhadap fenomena peristiwa yang sedang terjadi dari data yang telah didapatkan seperti data hasil observasi, data hasil wawancara, data hasil angket, dan data hasil dokumentasi

Pada penelitian ini, analisis data yang digunakan untuk menganalisis data adalah

\section{HASIL DAN PEMBAHASAN}

Sistem pemenuhan penjaminan mutu pendidikan itu tentu mempunyai sebuah pedoman atau ketentuan yang biasa kita sebut SOP ini ditetapkan sebagai suatu deskripsi petunjuk atau panduan instruksi kegiatan secara jelas sesuai dengan indikator-indikator pencapaian yang telah ditetapkan mengenai bagaimana cara mencapainya dengan ketentuan kerja yang dilakukan pada bidang pendidikan. Gambaran langkah-langkah kerja pada SOP ini diperlukan sebagai kelengkapan suatu kebijakan yang akan menjadi suatu sistem dan alur kerja yang jelas, teraut, sistematis, dan dapat dipertanggungjawabkan oleh suatu lembaga pendidikan dalam penjaminan mutunya. SOP menggunakan analisis data kualitatif interaktif milik Miles and Huberman (Sugiyono, 2013: 341) yaitu setelah data dikumpulkan kemudian dilakukan prosedur sebagai berikut: a) reduksi data (proses penyederhanaan pada data yang relevan sesuai dengan fokus penelitianya) digunakan untuk mengorganisi, mengelola, dan mengarahkan data agar dapat ditarik kesimpulan serta verifikasinya, b) penyajian data (data yang dsajikan berupa hasil reduksi data yang dirangkum dan disajikan secara terpadu) digunakan agar dapat meperoleh pemahaman mengenai fenomena-fenomena yang sedang terjadi pada penelitian, c) penarikan kesimpulan (didasarkan pada fenomena dan polapola yang terbentuk) digunakan untuk mendapatkan kesimpulan akhir yang sudah valid dan bukan lagi bersifat sementara mengenai penelitian ini.

dirumuskan secara relevan karena dapat digunakan untuk acuan tolak ukur ketika melakukan penilaian tujuan lembaga pendidikan secara efektif dan efisien berupa bentuk akreditasi sebuah lembaga pendidikan. Pada dasarnya SOP sudah disesuaikan dengan kebijakan dan peraturan yang sedang berlangsung saat ini. Berikut petunjuk Alur SOP Pelaksanaan Pejaminan Mutu Pendidikan berdasarkan dari Kemendikbud (2017: 3): 


\section{PRIMARY: JURNAL PENDIDIKAN GURU SEKOLAH DASAR VOLUME 9 NOMOR 3 JUNI 2020 \\ ISSN: 2303-1514 | E-ISSN: 2598-5949 \\ DOI : http://dx.doi.org/10.33578/jpfkip.v9i1.7905 \\ https://primary.ejournal.unri.ac.id/index.php/JPFKIP}

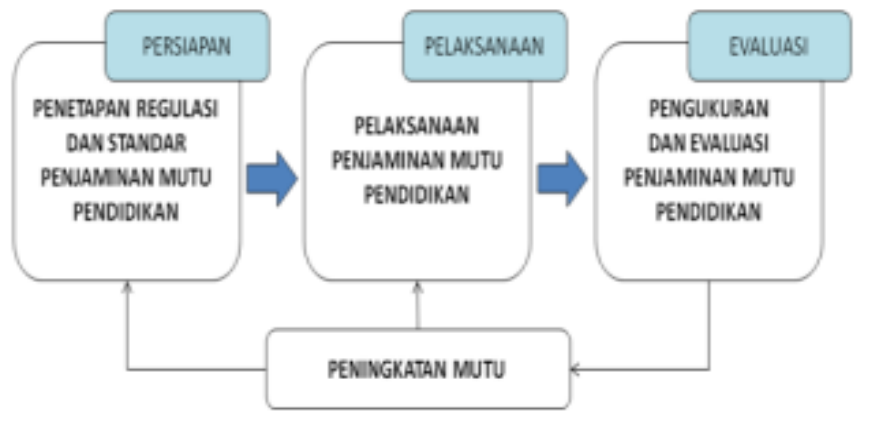

\section{Gambar 1. Alur Penjaminan Mutu Pendidikan Kemendikbud (2017: 3)}

Sistem pemenuhan dalam penjaminan mutu pendidikan ini diterapkan oleh satuan lembaga pendidikan dengan berkelanjutan dan berkesinambungan satu sama lainnya sehingga terbentuk sebuah budaya mengenai pentingya suatu penjaminan mutu pendidikan di satuan pendidikan perlu dijaga dan ditingkatkan. Hal ini tentu saja akan mendorong semangat dan motivasi satuan lembaga pendidikan dalam meningkatkan mutu pendidikan secara bertahap dan kontinu sehingga kebijakan Standar Nasional Pendidikan (SNP) Indonesia dapat terpenuhi secara optimal dan maksimal. Proses pemenuhan penjaminan mutu pendidikan ini haruslah menyediakan informasi terkait yang dibutuhkan sebagai dasar perencanaan dan pengambilan kebijakan peningkatan penjaminan mutu pendidikan dalam mencapai tujuan pendidikan yang berkualitas. Maka perlu pemahaman mengenai langkah prosedural bagaimana melakukan pemenuhan penjaminan mutu pendidikan sehingga nantinya hasil yang diperoleh sesuai dengan yang diharapkan dan direncanakan. Berikut ini hasil wawancara terkait impelementasi penjaminan mutu pendidikan di SD N 2 Bendosari Sawit Boyolali berdasarkan 8 SNP:

Tabel 1. Hasil Wawancara Mengenai 8 SNP

\begin{tabular}{|c|c|c|c|}
\hline No & Standar & Keterangan & Hasil \\
\hline 1 & Standar Isi & $\begin{array}{l}\text { Pada standar ini memuat mengenai kerangka dasar dan struktur } \\
\text { kurikulum yang digunakan sekolah }\end{array}$ & Baik \\
\hline 2 & Standar Proses & $\begin{array}{l}\text { Memuat mengenai perencanaan, pelaksanaan, dan pengawasan } \\
\text { proses pembelajaran yang berlangsung }\end{array}$ & $\begin{array}{c}\text { Sangat } \\
\text { Baik }\end{array}$ \\
\hline 3 & $\begin{array}{l}\text { Standar Kompetensi } \\
\text { Lulusan }\end{array}$ & $\begin{array}{l}\text { Meliputi standar kompetensi lulusan minimal dasar dan menengan, } \\
\text { standar kompetensi lulusan minimal kelompok mata pelajaran, dan } \\
\text { standar kompetensi lulusan minimal mata pelajaran. }\end{array}$ & Baik \\
\hline 4 & $\begin{array}{l}\text { Standar Pendidik dan } \\
\text { tenaga kependiikan }\end{array}$ & $\begin{array}{l}\text { Memuat kualifikasinya yaitu tingkat pendidikan minimal yang } \\
\text { harus dipenuhi oleh seorang pendidik yang dibuktikan dengan } \\
\text { ijazah dan sertifikat keahlian yang relevan sesuai dengan ketentuan } \\
\text { perundang-undangan. }\end{array}$ & $\begin{array}{c}\text { Sangat } \\
\text { Baik }\end{array}$ \\
\hline 5 & $\begin{array}{l}\text { Standar Sarana dan } \\
\text { Prasana }\end{array}$ & $\begin{array}{l}\text { Standar sarana dan prasarana yang meliputi fasilitas sekolah yang } \\
\text { memadai }\end{array}$ & Baik \\
\hline 6 & Standar Pengelolaan & $\begin{array}{l}\text { Terditi dari } 3 \text { bagian yakni standar pengelolaan oleh satuan } \\
\text { pendidikan, standar pengelolaan oleh pemerintah daerah, dan } \\
\text { standar pengelolaan oleh pemerintah. }\end{array}$ & $\begin{array}{c}\text { Sangat } \\
\text { Baik }\end{array}$ \\
\hline 7 & $\begin{array}{l}\text { Standar Pembiayaan } \\
\text { Pendidikan }\end{array}$ & $\begin{array}{l}\text { Standar ini meliputi biaya invetasasi, biaya operasi, dan biaya } \\
\text { operasional }\end{array}$ & Baik \\
\hline
\end{tabular}




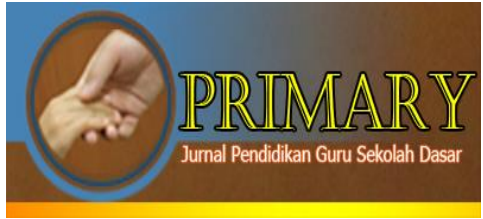

\section{PRIMARY: JURNAL PENDIDIKAN GURU SEKOLAH DASAR VOLUME 9 NOMOR 3 JUNI 2020 \\ ISSN: 2303-1514 | E-ISSN: 2598-5949 \\ DOI : http://dx.doi.org/10.33578/jpfkip.v9i1.7905 \\ https://primary.ejournal.unri.ac.id/index.php/JPFKIP}

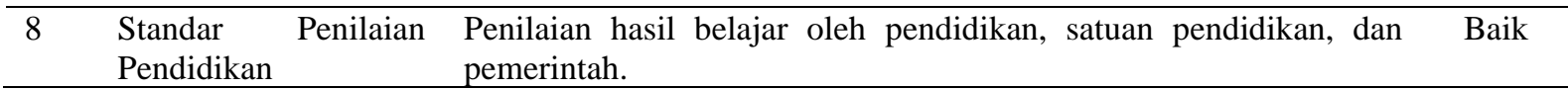

\section{PEMBAHASAN}

Standar operasional prosedur dalam pemenuhan penjaminan mutu pendidikan tersebut dilakukan dalam prosedur yang jelas, sistematis, kolaborasi antara pihak-pihak yang bersangkutan dan dilakukan secara konsisten. Menurut Direktorat Jenderal Pendidikan Dasar dan Menengah Kementrian Pendidikan dan Kebudayaan (2016: 13) bahwa langkah-langkah yang ditempuh dalam pemenuhan penjaminan mutu pendidikan suatu lembaga pendidikan sekolah terdiri atas: 1) perencanaan mengenai pemetaan penjaminan mutu pendidikan; 2) rancangan penyusunan rencana pemenuhan

\begin{abstract}
penjaminan mutu pendidikan; 3) realisasi pelaksanaan pemenuhan penjaminan mutu pendidikan; 4) pelaksanaan identifikasi permasalahan melalui evaluasi/audit dalam pemenuhan penjaminan mutu pendidikan; dan 5) rancangan penyusunan standar pemenuhan penjaminan mutu pendidikan yang baru di atas SNP guna memperbaiki kekurangan yang ada. Hal ini dilakukan sebagai landasan upaya nyata berupa tindakan untuk mengelola suatu lembaga pendidikan secara sistematis.
\end{abstract}

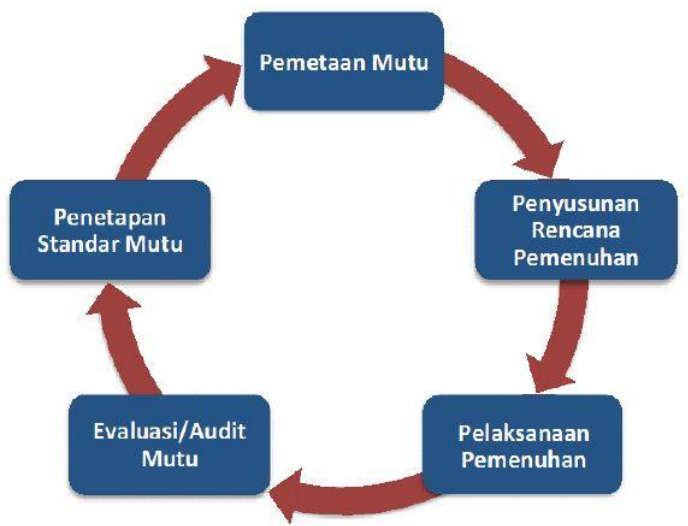

Gambar 2. Langkah-Langkah Penjaminan Mutu Pendidikan Kemendikbud (2016: 13)

\begin{abstract}
Sekolah dalam rangka pemenuhan penjaminan mutu pendidikan, dapat mengembangkan standar-standar yang ada, sesuai dengan langkah prosedural yang telah ditetapkan oleh pemangku kebijakan. Upaya ini digunakan untuk memberikan jaminan pelayanan yang berkualitas terhadap masyarakat sesuai dengan tujuan Nasional Pendidikan (Puspita: 2017: 3) Pemenuhan penjaminan mutu pendidikan yang dilakukan ini digunakan untuk menjaga kualitas
\end{abstract}

suatu lembaga pendidikan sekolah dan dapat digunakan juga untuk meningkatkan kualitasnya. Langkah-langkah prosedural tersebut dijelaskan tahap demi tahapnya agar diperoleh hasil yang maksimal sebagai berikut:

\section{Pemetaan Mutu Sebagai Upaya Meningkatkan Mutu Pendidikan \\ Upaya untuk meningkatkan pada di} sekolah diperlukan pemimpin yang handal yaitu 
seorang Kepala Sekolah yang berfungsi sebagai manajerial. Fungsi ini penting bagi Kepala Sekolah untuk mengatur setiap rencana, kegiatan, perangkat, laporan yang ada di lingkungan sekolah tempat dia menjadi pemimpin. Kepala Sekolah sebagai pemangku kepentingan yang berperan sebagai manajerial ini diharapkan dapat membimbing serta menjadi contoh untuk menggerakkan pendidik dan tenaga pendidikan dalam melaksanakan pemenuhan peningkatan mutu pendidikan di sekolah dasar serta pelayanan yang bermutu terhadap semua siswa. Kepala Sekolah berperan untuk memimpin dalam pembuatan dan pelaksanaan program Evaluasi Diri Sekolah (EDS) perlu dibahas dan dipahami secara benar oleh warga sekolah sebagai salah satu cara untuk pedoman dalam mengelola dan meningkatkan mutu pendidikan sekolah.

Penetapan pemenuhan standar mutu di SD N 2 Bendosari ini mengacu pada 8 SNP yang dirumuskan oleh BSNP dengan menyesuaikan peraturan-peraturan yang ada dan berlaku di indonesia saat ini. Visi, misi, dan kemampuan sekolah dalam pelaksanaanya juga ikut berperan memberikan kualitas dalam pelaksanaan program pemenuhan penjamian mutu pendidikan ini. Standar mutu ini dibahas dan dirumuskan bersama oleh warga sekolah diantaranya Komite Sekolah, Kepala Sekolah, Guru, Karyawan, Orang tua siswa, dan siswa, kemudian langkah yang dilakukan selanjutnya adalah mengenai pemetaan mutu pendidikan di sekolah. Pemetaan mutu di SD N 2 Bendosari dilaksanakan berdasarkan hasil program dari EDS dalam memetakan penjaminan mutu pendidikan melalui 8 SNP untuk mencapai tujuan sekolah. Pemetaan dalam pemenuhan penjaminan mutu 8 SNP ini, didukung dengan bukti fisik sesuai realita keadaan dilapangan.

Maka dapat menjelakan mengenai penjaminan mutu pendidikan di SD N 2 Bendosari secara benar, valid, dan akurat. Penjelasan mengenai pemenuhan penjaminan mutu sekolah ini, digunakan sebagai umpan baik dalam pengelolaan untuk mengembangkan mutu pendidikan melalui penyusunan program dan kegiatan peningkatan mutu yang dituangkan dalam RKT (Rencana Kerja Tahunan). Parwati \&
Suarnaya (2019: 6) berpendapat penyusunan RKT merupakan penjabaran dari sasaran dan program yang telah ditetapkan, dan akan dilaksanakan melalui kegiatan Tahunan. Upaya untuk meningkatkan mutu pendidikan sekolah ini jika dilaksanakan dengan baik, dianalisa dengan teliti, dipertanggungjawabkan dan dapat diawasi dengan mudah oleh lembaga terkait yang berguna sebagai dasar acuan perencanaan, pengambilan kebijakan, sumber dana, sumber daya manusianya, metode pencapaian yang digunakan, dan persaingan dengan sekolah lain.

Pembangunan untuk meningkatkan mutu pendidikan sekolah yang berkualitas haruslah memiliki prosedur yang jelas dan digunakan secara berkelanjutan dengan keterlibatan kerjasama antara lembaga sekolah dan lembaga terkait guna pengelolaan peningkatan mutu pendidikan. Pemetaan mutu ini digunakan untuk menilai pemenuhan standar dalam pendidikan yang telah ditetapkan, apakah sekolah sudah berhasil atau belum. Upaya-upaya yang dilakukan ini merupakan tujuan dalam jangka waktu yang lama, digunakan untuk mewujudkan tujuun pendidikan nasional secara jelas, detail, rinci, transparan sesuai dengan pedoman petunjuk yang telah ditetapkan. Senada dengan pendapat Puspitasari (2017: 346) menyatakan bahwa memetakan mutu pendidikan pada satuan pendidikan berdasarkan SNP melalui kegiatan evaluasi diri yang menghasilkan peta mutu (capaian standar), masalah yang dihadapi dan rekomendasi solusinya.

\section{Perencanaan Peningkatan Mutu Pendidikan}

Demi tercapainya tujuan peningkatan pendidikan nasional, sebuah sekolah perlu mengadakan sebuah program perencanaan. Program perencanaan ini disusun guna bagaimana langkah-langkah mencapai sebuah tujuan. Pada umumnya sebuah tujuan di sekolah tersebut bisa dilihat pada visi dan misi yang telah mereka susun. Hal ini sebagai acuan dalam pelaksanaan untuk mencapai sasaran dan target tersebut. Rencana peningkatan mutu pendidikan sekolah ini sudah dituangkan ke dalam rencana kerja tahunan (RKT). Perencanaan ini harus dilakukan secara optimal, efisien, dan efektif dalam menggunakan sumber daya sekolah dalam rangka mencapai tujuan yang 


\section{PRIMARY: JURNAL PENDIDIKAN GURU SEKOLAH DASAR VOLUME 9 NOMOR 3 JUNI 2020 \\ ISSN: 2303-1514 | E-ISSN: 2598-5949 \\ DOI : http://dx.doi.org/10.33578/jpfkip.v9i1.7905 \\ https://primary.ejournal.unri.ac.id/index.php/JPFKIP}

ingin dicapai. Hendaknya mampu secara jelas menyelesaikan permasalahan kesenjangan antara kondisi yang ada saat ini dan harapan yang ingin dicapai serta berorientasi pada masa depan yang baik.

Pada perencanaan peningkatan mutu pendidikan ini, SD $\mathrm{N} 2$ Bendosari menyusun perencanaan yang akan melakukan melalui beberapa langkah persiapan dengan melibatkan warga-warga sekolah yang ditunjuk yaitu membentuk panitia pelaksanaan, penyusunan jadwal, rencana sasaran pengisian angket, sosialisasi, rancangan diskusi dengan lembagalembaga terkait, anjang sana, study kerja ke sekolah daerah lain, mengikuti pembinaan serta pelatihan kerja pada workshop, lokakarya, seminar, bimbingan oleh lembaga yang berwenang yang berfungsi sebagai tempat meningkatkan kecakapan dan kualitas diri seseorang. RKT yang disusun ini adalah tahun 2019 yang didasarkan pada hasil mutu EDS tahun 2018 yang lalu, visi dan misi sekolah, tujuan sekolah, diskusi dan masukan dari beberapa pihak, dan kebijakan dari sekolah.

RKT ini dapat memberikan arah dan bimbingan pengelolaan sekolah dalam rangka perubahan yang lebih baik lagi dan mengurangi resiko kesalahan dalam pencapaian tujuan sekolah. RKT disusun berdasarkan dalam rangka pemenuhan mutu sesuai dengan 8 Standar Nasional Pendidikan dengan cara menetapkan sasaran, menetapkan program, menetapkan penanggungjawab program, menentukan kegiatan, dan menyusun jadwal kegiatannya. RKT yang telah dirumuskan oleh panitia penyusun kemudian dilakukan kaji ulang, dilakukan revisi dan disahkan oleh Pengawas Sekolah, Koordinator Paud Dikdas LS Kecamatan Sawit, dan Dinas Pendidikan dan Kebudayaan Kabupaten Boyolali. Pada akhirnya, RKT yang telah selesai ini, disosialisasikan kepada semua warga sekolah untuk kemudian bersamasama dijadikan dasar pelaksanaan kegiatan guna mencapai tujuan pendidikan Nasional.

\section{Implementasi Peningkatan Mutu Yang Dilakukan Sekolah}

Keterlibatan semua pihak warga sekolah mulai dari kepala sekolah masyarakat, orang tua siswa, siswa, guru, karyawan, dan komite sekolah secara totalitas bekerjasama dalam meningkatkan kualitas mutu pendidikan suatu lembaga sekolah dengan baik di dalamnya. Peningkatan mutu ini perlu dilakukan secara lebih terpadu dan serasi, dan harus disesuaikan dengan perkembangan ilmu pengetahuan dan teknologi di zaman yang memerlukan berbagai macam kemampuan, keterampilnya, dan keahlian di semua bidang. Pada pemenuhan implementasi mutu pendidikan di SD N 2 Bendosari ini berjalan dengan baik, hal ini merupakan hasil kerjasama dari warga sekolah dalam rangka mencapai visi, misi, dan tujuan sekolah. Pelaksanaan peningkatan mutu yang dilakukan ini merupakan hasil realisasi berdasarkan program RKT yang telah disusun sebelumnya dan dilaksanakan dengan penuh tanggungjawab.

RKT ini berisi mengenai pelaksanaan program dan kegiatan yang telah dirancang meliputi pemenuhan penjaminan mutu pendidikan dalam 8 Standar Nasional Pendidikan yaitu: 1) Pemenuhan mengenai standar isi, 2) pemenuhan mengenai standar proses, 3) pemenuhan mengenai standar kompetensi lulusan, 4) pemenuhan mengenai standar pendidik dan tenaga kependidikan, 5) pemenuhan mengenai standar sarana dan prasarana, 6) pemenuhan mengenai standar pengelolaan, 7) pemenuhan mengenai standar pembiayaan, dan 8) pemenuhan mengenai standar penilaian. Hajar (2017: 95) berpendapat bahwa implementasi dalam memenuhi mutu di lembaga pendidikan suatu sekolah merupakan program dan kegiatan hasil realisasi yang telah disusun sebelumnya dan berada dalam dokumen perencanaan peningkatan penjaminan mutu pendidikan yang harus dilaksanakan secara bertanggungjawab oleh semua pemangku kepentingan terkait.

Proses dalam implementasi penjaminan mutu sistem pendidikan ini, melalui analisis aspek pencapaian program dan skala prioritas peningkatan pada bagian tertentu. Warga sekolah memiliki kepentingan yang sama yaitu berkontribusi dalam penyenggalaran pendidikan yang bermutu. Data yang disediakan berupa perencanaan program dan pengambilan kebijakan 


\section{PRIMARY: JURNAL PENDIDIKAN GURU SEKOLAH DASAR VOLUME 9 NOMOR 3 JUNI 2020 \\ ISSN: 2303-1514 | E-ISSN: 2598-5949 \\ DOI : http://dx.doi.org/10.33578/jpfkip.v9i1.7905 \\ https://primary.ejournal.unri.ac.id/index.php/JPFKIP}

berdasarkan 8 Standar Nasional Pendidikan dalam mencapai tujuan sekolah. Pelaksanaan program dan kegiatan ini dilaksanakan dengan sebaik mungkin oleh seluruh pemangku kepentingan kebijakan sekolah dalam mengimplementasikan program yang telah direncakan dalam pemenuhan 8 SNP. Data yang diperoleh pada SD N 2 Bendosari, dalam rangka pelaksanaan peningkatan mutu pendidikan ini baik. Hal ini didasarkan pada kegiatan partisipasi aktif semua warga sekolah yang mengikuti program kegiatan yang dilaksanakan oleh sekolah.

Mulai dari Kepala Sekolah yang rajin membimbing dan mengarahkan sebagai pemimpin, para guru yang menjalankan tugasnya sesuai dengan fungsinya, rajin berpendapat, memberikan usulan, mengikuti rapat, karyawan sekolah yang bertugas menjaga sekolah serta merawatnya, siswa yang dengan senang hati mengikuti pembelajaran sekolah, orang tua yang mendukung siswa dalam pembelajaran, dan masyarakat yang ikut ambil bagian dalam kegiatan ekstrakulikuler seperti melatih beladiri siswa, mengajak siswa ikut TPA, dan melatih kegiatan pramuka. Semua kegiatan akademik siswa yang dilakukan oleh guru ini merupakan hasil pengembangan kreatifitas gutu dan disesuaikan dengan buku pedoman kurikulum yang berlaku serta pedoman mutu pendidikan.

\section{Evaluasi Atau Audit Mutu Yang Dilakukan Sekolah}

Evaluasi program ini adalah suatu kegiatan

yang dilaksanakan berdasarkan indikator pencapaian program untuk melihat keberhasilan program yang telah direncakan. Semua fungsi 8 Standar saling berkesinambungan dan melengkapi yang mempunyai kaitannya dalam pelaksanaan penjaminan mutu pendidikan harus dilaksanakan semaksimal mungkin sehingga dapat berjalan sesuai dengan layanan atau bahkan melebihan batas kriteria standarnya. Hal ini diperlukan manajemen dalam pengendalian mutu yang tepat yang dipimpin oleh kepala sekolah dimaksudkan agar kualitas suatu sekolah terjaga dan terjamin dengan baik secara terus-menerus bahkan dapat meningkat. Penjaminan mutu ini dilakukan secara bertanggungjawab dalam rangka mencapai tujuan sekolah. Pada tahapan ini, SD N 2 Bendosari melakukan evaluasi dalam rangka untuk penjaminan mutu sekolah melalui EDS untuk menilai hasil pelaksanaan pemenuhan penjaminan mutu 8 Standar dalam rangka mencapai tujuan sekolah.

Evaluasi juga dilihat dari terlaksananya program yang telah dirancang dan ditetapkan dalam RKT dan realitasi hasil pelaporan program kegiatannya kepada Lembaga terkait sesuai dengan tugasnya dalam melakukan Evaluasi Pendidikan. Hasil Evaluasi ini nantinya akan disampaikan oleh kepala sekolah kepada warga sekolah dalam rapat diskusi, apabila ditemukan sebuah permalahan yang dihadapi oleh sekolah, warga sekolah dapat memberikan saran dan usulan yang kemudian dijadikan rekomendasi dalam membuat rumusan mengenai perancangan RKT selanjutnya agar terjadi perbaikan dan peningkatan menuju yang lebih baik lagi dalam mencapai tujuan sekolah. Kegiatan diskusi yang dilakukan dalam rangka evaluasi pemenuhan penjaminan mutu ini dilakukan secara bertahap dalam kurun waktu tertentu yang sudah ditetapkan, yaitu setiap triwulan sekali bersama dengan warga sekolah untuk saling menyampaikan keluhan yang dirasakan maupun diamati yang terlibat dalam pelaksanaan program RKT yang telah disusun.

Sehingga dapat ditemukan permasalahanpermasalahan yang tentu akan dicari jalan keluar dan solusinya untuk mendukung perbaikan dan peningkatan dalam pelaksanaan program. Perlu adanya pemahaman mengenai bagaimana melaksanakan penjaminan mutu ini dengan baik, rinci, sistematis, efektif, dan efesien oleh warga sekolah, di mana hasilnya akan dapat digunakan sebagai pedoman dalam mencapai tujuan sekolah yang telah di rumuskan. Selain pemahaman, diperlukan juga kompetensi individu seperti keterampilan, keahlian, dan kemampuan yang tepat dan berkualitas dalam melaksanakan penjaminan mutu agar dalam pelaksanaannya terjamin bahwa mutu pendidikan ini akan mengalami peningkatan kualitas dan tercapainya indikator program. Pada akhirnya nanti hasil ini akan mengungkapkan 


\section{PRIMARY: JURNAL PENDIDIKAN GURU SEKOLAH DASAR VOLUME 9 NOMOR 3 JUNI 2020 \\ ISSN: 2303-1514 | E-ISSN: 2598-5949 \\ DOI : http://dx.doi.org/10.33578/jpfkip.v9i1.7905 \\ https://primary.ejournal.unri.ac.id/index.php/JPFKIP}

tingkat keberhasilan pelaksanaan yang telah dilakukan. Maka dapat dirumuskan langkahlangkah yang lebih baik dan produktif di perencanaan selanjutnya agar tercapai tujuan dari sekolah yang berkualitas.

\section{Penyusunan Standar Mutu Di atas SNP}

Penyusunan ini dimaksudkan agar sekolah dapat menetapkan standar-standar baru berdasarkan hasil rapat diskusi mengenai evaluasi dan audit sekolah dalam mencapai tujuan sekoah untuk menyusun strategi-strategi peningkatan mutu. Penyusunan ini tetap disertai dengan Visi, Misi, dan tujuan sekolah serta hasil evalusi sekolah mengenai kesulitan dan permasalahanpermasalahan yang terjadi terkait dengan pemenuhan 8 SNP dan implementasi program RKT yang telah direncanakan yang diharapkan akan memenuhi capaian kualitas sekolah sesuai 8 SNP atau bahkan dapat meningkat. Penyusunan standar mutu yang baru ini diharapkan menjadi sekolah yang berbudaya mutu yang dapat membentuk karakter pada siswa yaitu cerdas secara spiritual (SQ), secara emosional dan sosial (EQ), cerdas secara intelektual (IQ), dan cerdas secara kinestetis serta menghasilkan pembelajaran yang menyenangkan.

Penyusunan ini dilakukan sekolah untuk menjadi sekolah yang bermutu, beberapa peran wagra sekolahpun dapat mempengaruhinya seperti orang tua siswa yang terlibat aktif dalam mengawasi dan mendukung masing-masing anaknya, industri yang berperan aktif dalam menyediakan fasilitas-fasilitas pembelajaran seperti kursi, meja, alat peraga, bahan bangunan dan sebagainya, perguruan tinggi dan organisasi profesi yang berkontribusi besar dalam membentuk Sumber daya manusia pendidik-pendidik yang berkualitas, pemerintah yang berperan optimal secara jelas dan tepat dalam membimbing dan memberikan petunjuk, serta masyarakat sekitar yang peduli terhadap kemajuan mutu pendidikan sekolah. Hajar (2017: 95) berpendapat sekolah yang melaksanakan pendidikan yang bermutu sesuai dengan 8 standar nasional pendidikan yang telah ditetapkan BSNP adalah sekolah yang mempunyai kesadaran, kemampuan dari elemenelemen sekolah yang saling berkesinambungan dalam meningkatkan mutu pendidikan sekolahnya.

Apabila dalam tahapan ini standar belum terpenuhi, sekolah wajib memperbaiki strategi yang digunakan. Mas (2017: 30) berpendapat merujuk pada hasil audit evalusi yang telah dilakukan. Maka lembaga pendidikan harus merencanakan tindak lanjut sebagai langkah upaya perbaikan terhadap standar jika masih terdapat kekurangan dalam pencapaian standar. Tindak lanjut ini nantinya akan menjadi EDS di awal tahun, yang mana hal ini akan membentuk suatu siklus perbaikan dan peningkatan mutu sekolah secara berkelanjutan. Maka SD N 2 Bendosari sawit menetapkan terlebih dahulu kekurangankekurangan pemasalahan yang ada dan pencapaian tujuan baru yang ingin dicapai melalui strategi dan serangkaian kegiatan yang tepat melalui sebuah musyawarah dengan warga sekolah. Pencapaian tujuan ini akan dimonitor secara berkala, dievalusi, dan dikembangkan ke arah yang memiliki kualitas lebih baik dengan beberapa tahapan.

\section{SIMPULAN DAN REKOMENDASI}

Berdasarkan pemaparan hasil penelitian dan pembahasan, maka dapat disimpulkan bahwa dalam penelitian ini yaitu dalam pemenuhan mutu pendidikan yang dilakukan SD N 2 Bendosari untuk meningkatkan kinerja sekolah secara umum telah terlaksana dengan baik dan optimal. Hal ini didasarkan pada hasil EDS dan hasil diskusi dengan masyarakat mengenai program kegiatan yang telah dilaksanakan serta tercapainya indikator program yang telah ditetapkan. EDS ini, sesuai dengan prosedur pemenuhan kebijakan 8 standar mutu pendidikan nasional dalam upaya penyelenggaran sekolah dan mencapai tujuan sekolah, mulai dari 1) pemenuhan dalam standar isi, 2) pemenuhan dalam standar proses, 3) pemenuhan dalam standar kompetensi lulusan, 4) 


\section{PRIMARY: JURNAL PENDIDIKAN GURU SEKOLAH DASAR \\ VOLUME 9 NOMOR 3 JUNI 2020 \\ ISSN: 2303-1514 | E-ISSN: 2598-5949 \\ DOI : http://dx.doi.org/10.33578/jpfkip.v9i1.7905 \\ https://primary.ejournal.unri.ac.id/index.php/JPFKIP}

pemenuhan dalan standar pendidik dan tenaga kependidikan, 5) pemenuhan dalam standar sarana dan prasarana, 6) pemenuhan dalam standar pengelolaan, 7) pemenuhan dalam standar pembiayaan, dan 8) pemenuhan standar dalam penilaian pendidikan.

Prosedur alur yang digunakan SD N 2 Bendosaripun melalui 5 langkah yaitu 1) Pemetaan mutu sebagai upaya meningkatkan mutu pendidikan berdasarkan SNP melalui kegiatan EDS, 2) Perencanaan peningkatan mutu pendidikan berdasarkan hasil pemetaan mutu, dokumen kebijakan pendidikan satuan pendidikan, dan rencana aksi kegiatan serta rencana strategis pengembangan satuan pendidikan, 3) Implementasi peningkatan mutu yang dilakukan sekolah dalam pengelolaan satuan pendidikan dan kegiatan proses pembelajaran sehingga standar dapat tercapai, 4) Evaluasi atau audit mutu yang dilakukan sekolah digunakan untuk pengendalian terhadap proses pelaksanaan pemenuhan mutu yang telah dilakukan sesuai dengan perencanaan yang disusun untuk menjamin kepastian terjadinya peningkatan mutu yang berkelanjutan, dan 5) Penyusunan standar mutu di atas SNP digunakan untuk

\section{DAFTAR PUSTAKA}

Alawiyah, F. (2012). Penjaminan Mutu Pendidikan Tinggi. Jurnal aspirasi. Vol. 2 No. 1 Hal. 63-78. p-ISSN: 2086-6305. e-ISSN: 26145863

Kemendikbud. (2016). Sistem Penjaminan Mutu. Jakarta: Direktorat Jenderal Pendidikan Dasar dan Menengah Kementrian Pendidikan dan Kebudayaan.

Kusnandi. (2017). Konsep Dasar dan Strategi PenjaminanMutu Pendidikan: Sebagai Review Kebijakan Mutu Pendidikan. Indonesian Journal Of Education Management \& Administration Review. Vol. 1 No. 2 Desember 2017 Hal. 107-118.

Hajar R. (2017). Implementasi Penjaminan Mutu Pendidikan Dalam Meningkatkan Kinerja Madrasah: Studi di MTs Assurur dan MTs Arrohmah Kota Tasikmalaya. Indonesian Journal of Education Management \& memperbaiki strategi dalam pemenuhan mutu terutama pada standar yang masih belum terpenuhi berdasarkan hasil audit/evaluasi.

Beberapa solusi dan saran dalam pada penyusunan perencanaan mutu yang dilakukan dalam rangka meningkatkan kinerja sekolah ini ditunjukkan adanya ketercapainya indikator pelaksanaan dalam penyusunan program kegiatan sekolah, pengumpulan informasi yang objektif mengenai pemenuhan $8 \mathrm{SNP}$, perbaikan dan revisi serta perumusan visi, misi, dan tujuan sekolah yang baru, pemenuhan jadwal kegiatan, dan waktu yang dibutuhkan secara jelas. Komunikasi yang aktif dari sekolah ke masyarakat diperlukan dalam adanya penyampaian masalah-masalah dan solusi perbaikannya, akan mengarahkan sekolah ke arah yang lebih baik lagi. Apabila hal-hal ini tersebut sudah diterapkan dan dilaksanakan, maka menandakan bahwa sekolah tersebut sudah melaksanakan pemenuhan mutu pendidikan dengan perencanaan yang baik. Dukungan serta kerjasama dari berbagai pihak warga sekolah juga mnejadi kunci yang penting dalam memenuhi standar nasional pendidikan dalam mencapai tujuan pendidikan.

Administration Review. Vol. 1 No. 1 Juni 2017 Hal. 89-98.

Haryono, Budiyono, Istyarini, Warddi, Ardiantoro, A. (2019). Sistem Penjaminan Mutu Pendidikan Dalam Meningkatkan Mutu Pendidikan Sekolah Dasar Di Kecamatan Gajah Mungkur Kota Semarang. Jurnal Panjar: Pengabdian Bidang Pembelajaran.Vol. 1 No. 2 April 2019. Hal 17-22. ISSN: 2656-2405.

Kemendikbud. (2017). Perangkat Instrumen Pemetaan Mutu Pendidikan Dasar dan Menengah. Jakarta: Direktorat Jenderal Pendidikan Dasar dan Menengah Kementrian Pendidikan dan Kebudayaan.

Mas, S. R. (2017). Pengelolaan Penjaminan Mutu Pendidikan. Yogyakarta: Zahr Publishing

Meirawan, D. (2010). Penjaminan Mutu Satuan Pendidikan Sebagai Upaya Pengendalian 


\section{PRIMARY: JURNAL PENDIDIKAN GURU SEKOLAH DASAR \\ VOLUME 9 NOMOR 3 JUNI 2020 \\ ISSN: 2303-1514 | E-ISSN: 2598-5949 \\ DOI : http://dx.doi.org/10.33578/jpfkip.v9i1.7905 \\ https://primary.ejournal.unri.ac.id/index.php/JPFKIP}

Mutu Pendidikan Secara Nasional Dalam Otonomi Pendidikan. Jurnal EDUCATIONIST. Vol. 4 No. 2 Juli 2010. Hal. 126-137. ISSN: 1907-8838.

Parwati, N. K. I. \& Suarnaya, I. K. (2019). Kolaborasi Penjaminan Mutu Pendidikan: Kajian Hasil Analisis Monerv SPMETPMPD. Bali: Lembaga Penjaminan Mutu Pendidikan Bali.

Puspitasari, H. (2017). Standar Proses Pembelajaran Sebagai Sistem Penjaminan Mutu Internal Di Sekolah. Muslim Heritage Journal. Vol. 1 No. 2 November 2017. Hal: 339-368.

Puspita, A. C. (2017). Impelementasi Penjaminan Mutu Di Sekolah Dasar Muhammadiyah 1 Ketelan Surakarta. Skripsi. Surakarta: Universitas Muhammadiyah Surakarta.
Sugiyono. (2013). Metode Penelitian Kuantitatif, Kualitatif, dan $R \& D$. Bandung: Alfabeta.

Sulaiman A. \& Budi U. (2016). Implementasi Sistem Penjaminan Mutu Internal Sebagai Upaya Meningkatkan Mutu Pendidikan Di Universitas Gadjah Mada. Jurnal Akuntabilitas Manajemen Pendidikan. Vol. 4 No. 1 April 2015 Hal. 17-32. p-ISSN: 2337-7895. e-ISSN: 2461-0550.

Uchtiawati S. \& Zawawi I. (2014). Penerapan Penjaminan Mutu Pendidikan Pada Sekolah Menegah Atas Berstandar Internasional. Jurnal Kebijakan Dan Pengembangan Pendidikan. Vol. 2 No.1 Januari 2014 Hal. 52-56. p-ISSN: 2337-7623. e-ISSN: 23377615. 